\title{
AKTIVITAS EKSTRAK ETANOL BUAH BELIMBING WULUH (Averrhoa bilimbi L) TERHADAP PENURUNAN KADAR GLUKOSA DARAH MENCIT JANTAN (Mus musculus)
}

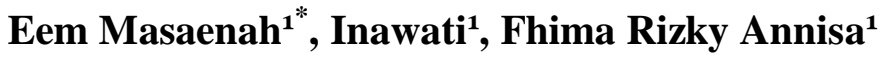 \\ ${ }^{1}$ Program Studi Farmasi Sekolah Tinggi Teknologi Industri dan Farmasi Bogor \\ *Korespondensi: masaenaheem@gmail.com, eem@sttif.ac.id
}

\begin{abstract}
ABSTRAK
Diabetes Melitus (DM) termasuk kelompok penyakit metabolik yang ditandai dengan tingginya kadar glukosa darah. Hal ini disebabkan oleh gagalnya pankreas menghasilkan insulin atau kerja insulin yang terganggu (resistensi insulin). Tujuan penelitian untuk mengetahui aktivitas ekstrak etanol $70 \%$ buah belimbing wuluh (Averrhoa bilimbi L) terhadap penurunan kadar glukosa darah mencit jantan (Mus musculus) galur Swiss Webster yang diinduksi aloksan. Sebanyak 30 ekor mencit jantan dibagi dalam 6 kelompok perlakuan yaitu kelompok kontrol normal, kontrol negatif (Na CMC), kontrol positif (Metformin $65 \mathrm{mg} / \mathrm{kg} \mathrm{bb}$ ), kelompok ekstrak buah belimbing wuluh $250 \mathrm{mg} / \mathrm{kg} \mathrm{bb}, 500$ $\mathrm{mg} / \mathrm{kg} \mathrm{bb}$, dan $750 \mathrm{mg} / \mathrm{kg}$ bb. Data diperoleh dari pemeriksaan kadar glukosa darah menggunakan glucometer easytouch ${ }^{\circledR}$, yaitu kadar glukosa darah puasa sebelum induksi, setelah diinduksi, dan setelah pemberian ekstrak pada masing-masing kelompok perlakuan. Hasil penelitian menunjukkan buah belimbing wuluh dengan dosis $250 \mathrm{mg} / \mathrm{kg} \mathrm{bb}, 500$ $\mathrm{mg} / \mathrm{kg} \mathrm{bb}$, dan $750 \mathrm{mg} / \mathrm{kg}$ bb dapat menurunkan kadar glukosa darah mencit jantan yang diinduksi aloksan. Diduga senyawa aktif ekstrak etanol $70 \%$ buah belimbing wuluh berperan dalam meningkatkan sensitifitas reseptor insulin dan mengakibatkan glukosa dapat diambil oleh sel untuk dimetabolisme. Berdasarkan hasil yang diperoleh dapat disimpulkan bahwa ekstrak etanol $70 \%$ buah belimbing wuluh dengan dosis $750 \mathrm{mg} / \mathrm{kg} \mathrm{bb}$ merupakan dosis yang paling efektif terhadap penurunan kadar glukosa darah.
\end{abstract}

Kata kunci: Aloksan, Averrhoa bilimbi L, kadar glukosa darah, mencit jantan (Mus musculus)

\begin{abstract}
Diabetes Mellitus (DM) is a group of metabolic diseases characterized by high blood glucose levels. This is caused by the failure of the pancreas to produce insulin or impaired insulin action (insulin resistance). The purpose of this study was to determine the activity of $70 \%$ ethanol extract of starfruit fruit (Averrhoa bilimbi L) on the decrease in blood glucose levels in male mice (Mus musculus) strain of Webster induced by alloxan. A total of 30 male mice were divided into 6 treatment groups namely normal control group, negative control (Na CMC), positive control (Metformin $65 \mathrm{mg} / \mathrm{kg} \mathrm{bw}$ ), star fruit extract group $250 \mathrm{mg} / \mathrm{kg} \mathrm{bw}, 500 \mathrm{mg} / \mathrm{kg} \mathrm{bw}$, and $750 \mathrm{mg} / \mathrm{kg}$ bw. Data obtained from examination of blood glucose levels using an easy touch ${ }^{\circledR}$ glucometer, namely fasting glucosadarah levels before induction, after induction, and after administration of extracts in each treatment group. The results showed that starfruit with a dose of $250 \mathrm{mg} / \mathrm{kg} \mathrm{bw}, 500$ $\mathrm{mg} / \mathrm{kg} \mathrm{bw}$, and $750 \mathrm{mg} / \mathrm{kg}$ bw can reduce blood glucose levels in male mice that are induced by alloxan. Allegedly the active compound extract of $70 \%$ ethanol starfruit fruit plays a role in increasing the sensitivity of insulin receptors and resulting in glucose can be taken up by cells to be metabolized. Based on the results obtained it can be concluded that the ethanol extract of $70 \%$ starfruit fruit with a dose of $750 \mathrm{mg} / \mathrm{kg}$ bw is the most effective dose to decrease blood glucose levels.
\end{abstract}

Keywords: Alloxan, Averrhoa bilimbi L, blood glucose level, male mice (Mus musculus) 


\section{PENDAHULUAN}

Menurut American Diabetes

Association (ADA), Diabetes Melitus (DM) termasuk kelompok penyakit metabolik yang ditandai dengan tingginya kadar glukosa darah. Hal ini dapat disebabkan oleh gagalnya pancreas menghasilkan insulin atau kerja insulin yang terganggu/resistensi insulin [1].

Laporan WHO pada tahun 2016 menunjukkan bahwa jumlah penderita DM hampir empat kali lipat sejak 1980 sampai 422 juta orang dewasa. Sedangkanmenurut Badan Kesehatan Dunia memprediksi kenaikan jumlah penderita DM di Indonesia dari 8,4 juta pada tahun 2000 akan menjadi sekitar 21,3 juta pada tahun 2030 [2]. Maka dari itu perlu dikaji lebih lanjut mengenai diabetes Melitus, serta terapi yang tepat untuk mengurangi diabetes Melitus yang terus mengalami peningkatan [3].

Adanya peningkatan jumlah penderita DM setiap tahunnya serta biaya pengobatan yang mahal terutama jika disertai komplikasi mendorong masyarakat untuk menggunakan obat tradisional yang dapat dipakai sebagai alternatif pengobatan. Oleh sebab itu makin banyak dikembangkan penanganan DM dengan menggunakan tanaman tradisional [3].

Salah satu tanaman yang dapat dipakai untuk mengatasi masalah DM yaitu belimbing wuluh (Averrhoa bilimbi L). Tanaman ini mudah didapatkan, dikenal banyak orang namun masih sedikit penelitian lebih lanjut mengenai khasiatnya.

Berdasarkan penelitian sebelumnya, ekstrak etanol $96 \%$ buah dan daun belimbing wuluh mengandung flavonoid dan saponin yang bersifat antihiperglikemik [2]. Penelitian lain, pemberian ekstrak etanol daun belimbing wuluh mampu menurunkan kadar glukosa darah sebesar $50 \%$ pada tikus galur wistar yang diinduksi dengan streptozotocin [4].

Penelitian lain menyebutkan ekstrak etanol70\% batang belimbing wuluh mengandung saponin dan tanin, mampu menurunkan kadar glukosa darah tikus yang diinduksi aloksan dengan dosis $25 \mathrm{mg} / \mathrm{kg}$, $50 \mathrm{mg} / \mathrm{kg}$ dan $100 \mathrm{mg} / \mathrm{kg}$ [5]. Hasil penelitian lain menyebutkan ekstrak etanol
$70 \%$ buah belimbing wuluh dan daun tapak dara dengan dosis $20 \mathrm{~g} / 200 \mathrm{~g}, 40 \mathrm{~g} / 200 \mathrm{~g}$, dan $80 \mathrm{~g} / 200 \mathrm{~g}$ berat tikus galur wistar yang diinduksi aloksan $30 \mathrm{mg} / 200 \mathrm{~g}$ bb mampu menurunkan kadar glukosa darah [6].

Penelitian infusa buah belimbing wuluh dengan dosis $0,756 \mathrm{~g} / 20 \mathrm{~g}$ mencit yang diinduksi aloksan dapa tmenurunkan kadar glukosa darah puasa [7]. Penelitian lain menyatakan bahwa pemberian ekstrak etanol $96 \%$ buah belimbing wuluh selama 14 hari dengan dosis $750 \mathrm{mg} / \mathrm{kg}$ berat badan efektif menurunkan kadar glukosa darah pada tikus wistar [8].

Atas dasar acuan penelitian-penelitian di atas, peneliti ingin membuktikan apakah ekstrak etanol $70 \%$ buah belimbing wuluh dengan perlakuan selama 7 hari juga dapat menurunkan kadar glukosa darah. Peneliti menggunakan mencit jantan galur swiss webster sebagai hewan percobaan dan melakukan induksi aloksan terhadap mencit jantan tersebut untuk menciptakan kondisi hiperglikemia.

\section{METODE PENELITIAN Alat dan Bahan}

Peralatan yang digunakan adalah kendang mencit yang terbuat dari kawat dan bak plastik sebanyak 6 kandang, tempat air minum dan makanan mencit, timbangan digital (ACS AD-300i), oven (Memmert), rotary vacuum evaporator (IKA RV 10 basic), waterbath, lumpang dan alu, masker, gunting, sarung tangan, sonde oral ukuran $1 \mathrm{ml}$, needle no. 26 , spuit terumo 1 $\mathrm{ml}$, botol $50 \mathrm{ml}$, strip glukotest dan alat pengukur gula darah glucometer Easy Touch, dan alat-alat gelas.

Bahan yang digunakan yaitu buah belimbing wuluh yang diperoleh dari daerah lingkungan RSI Cempaka Putih Jakarta Pusat. Bahan lain yang dibutuhkan antara lain $\mathrm{HCl}$, pereaksi Meyer yang terdiri dari $\mathrm{HgCl}_{2}$ dan larutan $\mathrm{KI}$, pereaksi Wagner terdiri dari larutan iodin dan KI, pereaksi dragendorff terdiri dari larutan bismuth nitrat basa dalam asam asetat glasial dengan KI dalam air, pereaksi $\mathrm{FeCl}_{3}$, asam sulfat 2 M, kloroform, amil alkohol, serbuk magnesium, asam asetat anhidrat, asam 
39 Eem Masaenah et al., (Aktivitas Ekstrak Etanol Buah Belimbing Wuluh...)

sulfat pekat, etanol $70 \%$, aloksan, Na-CMC aqua destilata, pakan ternak, larutan $\mathrm{NaCl}$ $0,9 \%$, tablet metformin $500 \mathrm{mg}$.

\section{Persiapan Hewan Uji}

Hewan uji dipilih sebanyak 30 ekor mencit jantan secara acak yang dibagi menjadi 6 kelompok perlakuan, yaitu 1) kelompok normal, 2) kelompok ekstrak dosis $250 \mathrm{mg} / \mathrm{kg} \mathrm{bb}, 3)$ kelompok dosis 500 $\mathrm{mg} / \mathrm{kg} \mathrm{bb}, 4)$ kelompok dosis $750 \mathrm{mg} / \mathrm{kg}$ bb, 5) kelompok kontrol positif metformin $65 \mathrm{mg} / \mathrm{kg}$ bb, dan 6) dan kelompok kontrol negatif $\mathrm{Na} \mathrm{CMC} 0,5 \% \mathrm{~b} / \mathrm{v}$.

\section{Prosedur Kerja \\ Pembuatan Simplisia}

Sampel berupa buah belimbing wuluh (Averrhoa bilimbi $\mathrm{L}$ ) yang segar berwarna hijau kekuningan sebanyak 1,7 kg. Buah dicuci dengan air mengalir sampai bersih kemudian ditiriskan untuk membebaskan buah dari sisa-sisa air cucian. Buah dipisahkan dari bijinya lalu dirajang tipistipis dengan ketebalan kurang lebih $0,5 \mathrm{~cm}$. Kemudian dikeringkan di dalam oven dengan suhu $50^{\circ} \mathrm{C}$ selama 5 hari. Simplisia kering disortasi dan dihaluskan dengan blender serta diayak dengan ayakan no. 40 mesh. Serbuk yang sudah jadi disimpan dalam wadah tertutup rapat [9].

\section{Penetapan Kadar Air}

Penetapankadar air serbuk buah belimbing wuluh dilakukan dengan cara menguapkan air yang ada di dalam bahan dengan jalan pemanasan menggunakan oven sehingga air menguap [10].

Kadar air $(\%)=\frac{a-b}{a} \times 100 \%$ $\mathrm{a}=$ bobot sampel sebelum pemanasan $(\mathrm{g})$ $\mathrm{b}=$ bobot sampel setelah pemanasan $(\mathrm{g})$

\section{Penapisan Fitokimia [11]}

\section{a. Flavonoid}

Simplisia serbuk buah belimbing wuluh sebanyak 3gram ditambah10 ml air dan dipanaskan selama 5 menit selanjutnya disaring dan filtratnya ditambahkan $500 \mathrm{mg}$ serbuk magnesium dan 2 tetes $\mathrm{HCl}$. Kemudian ditetesi 2 amil alkohol. Hasil ditunjukkan dengan munculnya warna merah tua pada lapisan amil alcohol menunjukkan adanya senyawa flavonoid.

\section{b. Saponin}

Simplisia serbuk buah belimbing wuluh sebanyak 3 gram ditambahkan $10 \mathrm{ml}$ air dan dipanaskan selama 5 menit selanjutnya disaring dan filtratnya diambil sebanyak $5 \mathrm{ml}$, dimasukkan ke dalam tabung reaksi. Kemudian larutan dikocok selama 10 detik, dibiarkan selama 10 menit. Uji positif ditandai dengan terbentuknya buih yang stabil.

\section{c. Alkaloid}

Simplisia serbuk buah belimbing wuluh sebanyak 1 gram ditambah 2 tetes $\mathrm{NH}_{3}$ dan $5 \mathrm{ml}$ kloroform, kemudian disaring. Filtratnya ditambahkan asam sulfat $2 \mathrm{M}$. Lapisan asam yang terbentuk ditetesi dengan 3 pereaksi. Uji positif alkaloid dengan larutan pereaksi Dragendorff akan menghasilkan warna oranye, larutan pereaksi Mayer akan menghasilkan warna putih, dan pereaksi Wagner akan menghasilkan warna coklat.

\section{d. Tanin}

Simplisia serbuk buah belimbing wuluh sebanyak 3 gram ditambah $10 \mathrm{ml}$ akuades, dipanaskan selama 5 menit. Kemudian disarin, filtratnya ditambahkan 3 tetes $\mathrm{FeCl}_{3} 10 \%$. Uji positif tanin ditandai dengan terbentuknya warna hitam.

\section{e. Kuinon}

Simplisia serbuk buah belimbing wuluh sebanyak 1 gram ditambahkan metanol, dipanaskan, dan disaring. Filtratnya ditambah 3 tetes $\mathrm{NaOH} 10 \%$. Uji positif ditandai dengan terbentuknya warna merah.

\section{f. Steroid dan Triterpenoid}

Simplisia serbuk buah belimbing wuluh sebanyak 1 gram ditambah etanol, dan disaring Filtratnya dipanaskan hingga kering. Kemudian ditambahkan $1 \mathrm{ml}$ dietil eter, aduk hingga homogen. Selanjutnya ditambahkan 1 tetes asam sulfat, dan 1 tetes asam asetat anhidrat. Hasil uji positif steroid ditandai dengan terbentuknya warna hijau kebiruan. Hasil uji positif triterpenoid 
40 Eem Masaenah et al., (Aktivitas Ekstrak Etanol Buah Belimbing Wuluh...)

ditandai dengan terbentuknya warna ungu kemerahan.

\section{Pembuatan Ekstrak Etanol 70\% Buah Belimbing Wuluh}

Serbuk simplisia buah belimbing wuluh sebanyak 120 gram dimaserasi dengan etanol $70 \%$ selama $3 \times 24$ jam. Tiap $1 \times 24$ jam dilakukan penyaringan dan diremaserasi. Kemudian, filtrat dijadikan satu dan dipekatkan menggunakan rotary evaporator pada suhu $40^{\circ} \mathrm{C}$ selama 8 jam sehingga menghasilkan ekstrak kental etanol $70 \%$. Ekstrak kental yang diperoleh ditimbang kemudian nilai persentase rendemen dihitung menggunakan rumus berikut:

$$
R=\frac{\text { Bobot ekstrak kental }}{\text { Bobot simplisia yang diekstraksi }} \times 100 \%
$$

Pembuatan Suspensi Metformin dan Ekstrak Buah Belimbing Wuluh

a. Serbuk metformin ditimbang sebanyak $70 \mathrm{mg}$, kemudian dilarutkan dalam $10 \mathrm{ml}$ suspending agent Na-CMC 0,5\% b/v. Rata-rata berat badan mencit 27 gram. Volume pemberian per oral yang diberikan sebanyak $0,5 \mathrm{ml}$ pada masingmasing mencit.

b. Ekstrak buah belimbing wuluh ditimbang masing-masing sebanyak 135 $\mathrm{mg}, 270 \mathrm{mg}$, dan $405 \mathrm{mg}$. Kemudian masing-masing ekstrak dilarutkan dalam $10 \mathrm{ml}$ larutan suspending agent $\mathrm{Na} \mathrm{CMC}$ $0,5 \% \mathrm{~b} / \mathrm{v}$. Volume pemberian per oral maksimal diberikan sebanyak $1 \mathrm{ml}$ pada masing-masing mencit.

\section{Pembuatan Larutan aloksan}

Serbuk aloksan sebanyak $100 \mathrm{mg}$, dilarutkan dalam larutan $\mathrm{NaCl} \quad 0,9 \quad \%$ sebanyak $10 \mathrm{ml}$. Dosis yang diperlukan untuk mencit sebanyak 4,54 mg. Diambil dari campuran larutan tersebut sebanyak $0,45 \mathrm{ml}$. Volume pemberian injeksi intra peritoneal diberikan sebanyak $0,45 \mathrm{ml}$ pada masing-masing mencit.

\section{Pengujian Kadar Glukosa Darah pada Mencit Sebelum Diinduksi}

a. Mencit jantan dikelompokkan dalam 6 kelompok penelitian, masing-masing sejumlah 5 ekor. Semua kelompok diadaptasikan selama 7 hari dengan pemberian makanan dan minuman sebanyak satu kali pada pagi hari.

b. Di hari ke-8, kelompok perlakuan dosis $250 \mathrm{mg} / \mathrm{kg} \mathrm{bb}, 500 \mathrm{mg} / \mathrm{kg} \mathrm{bb}, 750 \mathrm{mg} / \mathrm{kg}$ $\mathrm{bb}$, kontrol negatif NaCMC $0,5 \% \mathrm{~b} / \mathrm{v}$, dan kontrol positif metformin $65 \mathrm{mg} / \mathrm{kg}$ bb dipuasakan selama 8 jam, sedangkan kelompok normal tidak dipuasakan.

c. Kemudian diukur kadar glukosa darah puasa, yakni antara 50-109 mg/dl [12]. Sampel darah diambil dengan cara dipotong ujung ekor mencit. Darah diletakkan pada test strip, kemudian strip dimasukkan ke dalam alat glukometer untuk diukur kadar glukosa darah awal.

\section{Pengujian Kadar Glukosa Darah Pada Mencit Setelah Diinduksi}

a. Pada hari ke-8 setelah pengukuran awal glukosa darah, kelompok perlakuan, kontrol negatif, dan kontrol positif diinduksi aloksan (120 mg/kgbb) secara intraperitoneal [13, 14], sedangkan kelompok normal tidak diinduksi.

b. Setelah diinduksi, 2 hari kemudian mencit diukur kadar glukosa darahnya dengan menunjukkan kadar glukosa darah hiperglikemia yaitu dengan kadar 200-349 mg/dl [15].

\section{Pengujian Farmakologi Ekstrak Etanol $70 \%$ Buah BelimbingWuluh}

a. Setelah mendapatkan kadar glukosa darah mencit yang mencapai hiperglikemia, 6 kelompok mencit jantan diberi perlakukan per oral pada pagi hari selama 7 hari.

b. Setelah perlakuan selama 7 hari, kemudian dilakukan pengukuran kadar glukosa darah di hari berikutnya.

\section{Analisis Data}

Data yang diperoleh dianalisis dengan uji Analisis of Variance (ANOVA) satu arah yaitu RAL (rancangan acak lengkap) dan uji lanjutan LSD (Least Significant Differences). 


\section{HASIL DAN PEMBAHASAN Preparasi Sampel}

Buah belimbing wuluh diambil pada pukul 10.00-12.00 WIB karena proses fotosintesis yang maksimal terjadi pada waktu tersebut. Buah yang diambil adalah buah yang masak berwarna hijau kekuningan. Hal ini bertujuan agar buah yang diperoleh dapat menghasilkan metabolit sekunder yang lebih banyak [16]. Buah yang dipilih tersebut dicuci dengan air bersih selanjutnyadirajang untuk membantu mempercepat proses pengeringan. Pengeringan dilakukan dengan mesin oven pada suhu $50^{\circ} \mathrm{C}$ selama 5 hari. Hal ini dimaksudkan agar tidak merusak kandungan flavonoid di dalam simplisia buah belimbing wuluh.

Penghalusan dan pengayakan bertujuan untuk memperbesar luas permukaan dan penyeragaman ukuran partikel agar kontak antara bahan dan larutan penyari lebih besar. Selanjutnya simplisia disimpan dalam wadah kedap udara untuk mempertahankan kadar air yang minimal dan menghindari tumbuhnya jamur. Sebanyak $1,7 \mathrm{~kg}$ buah belimbing wuluh menghasilkan 120 gram simplisia serbuk.

Hasil penetapan kadar air diperoleh sebesar $17,18 \%$. Seharusnya simplisia dinilai cukup aman bila mempunyai kadar air kurang dari 10\%. Sehingga mempengaruhi kualitas dan daya simpan dari simplisia buah belimbing wuluh. Semakin banyak kadar air yang terkandung, umur simpannya semakin cepat, hal ini menyebabkan adanya mikroba yang tumbuh.

\section{Hasil Penapisan Fitokimia}

Penapisan fitokimia dilakukan untuk memperoleh informasi awal mengenai senyawa kimia yang mempunyai aktivitas biologis dari suatu tanaman. Hasil penapisan fitokimia secara kualitatif menunjukkan bahwa ekstrak etanol $70 \%$ buah belimbing wuluh mengandung metabolit sekunder flavonoid.

Tabel 1. Hasil Penapisan Fitokimia Buah Belimbing Wuluh

\begin{tabular}{|l|c|}
\hline Pengujian Fitokimia & Hasil \\
\hline Saponin & $(-)$ \\
\hline Flavonoid & $(+)$ \\
\hline Alkaloid & $(-)$ \\
\hline Tanin & $(-)$ \\
\hline Kuinon & $(-)$ \\
\hline Steroid/Triterpenoid & $(-)$ \\
\hline
\end{tabular}

Keterangan :+ = terdeteksi

$$
=\text { tidak terdeteksi }
$$

Hasil yang diperoleh pada pemeriksaan fitokimia menunjukkan adanya kandungan senyawa flavonoid. Hal ini ditandai dengan terbentuknya warna kuning pada saat penambahan $\mathrm{HCl}$ pekat. Warna kuning yang dihasilkan menandakan adanya flavonoid akibat reduksi oleh asam klorida pekat dan magnesium [17].

Uji saponin dilakukan dengan mengocok kuat-kuat selama 10 detik. Adanya saponin ditandai dengan terbentuknya busa setinggi $1-10 \mathrm{~cm}$ yang stabil tidak kurang dari 10 menit dan tidak hilang dengan penambahan 1 tetes $\mathrm{HCl} 2 \mathrm{~N}$.
Penambahan $\mathrm{HCl}$ berfungsi untuk menghidrolisis senyawa sehingga busa yang terjadi lebih lama. Hasil pemeriksaan menunjukkan bahwa ekstrak tidak mengandung saponin karena tidak terbentuk busa yang stabil.

Pengujian senyawa alkaloid dilakukan dengan menggunakan pereaksi Mayer dan Dragendorff. Prinsip metode ini adalah reaksi pengendapan yang terjadi karena adanya penggantian ligan. Atom nitrogen yang mempunyai pasangan elektron bebas pada alkaloid dapat mengganti iod-iod dalam reagen Mayer dan Dragendorff. 
Indikator positif dari uji alkaloid adalah terbentuknya endapan merah atau jingga pada pereaksi Dragendorff, endapan putih kekuningan pada pereaksi Meyer dan endapan coklat pada pereaksi Wagner. Hasil negatif yang didapatkan ini kemungkinan dipengaruhi oleh lokasi sampel penelitian yang mempengaruhi laju metabolisme pada buah belimbing wuluh.

Pada uji tanin, indikator positif dilihat dengan terbentuknya larutan berwarna hijau kehitaman atau biru tinta. Berdasarkan hasil identifikasi, tanin negatif ditemukan pada simplisia buah belimbing wuluh karena terbentuk warna larutan kuning keruh. Pada uji kuinon, indikator positif dilihat dengan terbentuknya warna merah dan endapan. Kuinon adalah senyawa berwarna dan mempunyai kromofor dasar yang terdiri atas dua gugus karbonil dengan dua ikaratn rangkap karbon-karbon. Warna kuinon beragam, mulai dari kuning pucat hingga kehitaman. Berdasarkan hasil identifikasi, kuinon negatif ditemukan pada uji fitokimia karena hanya terbentuk warna oranye keruh dan tidak ada endapan.

Pada uji triterpenoid dan steroid indikator positif dilihat dengan terbentuknya larutan berwarna merah untuk pertama kali pada reaksi positif triterpenoid dan selanjutnya terbentuknya larutan biru dan hijau untuk reaksi positif steroid. Hasil negatif pada uji triterpenoid dan steroid, dimana triterpenoid tersusun dari rantai panjang hidrokarbon C30 yang menyebabkan sifat non polar sehingga tidak terekstrak dalam pelarut yang bersifat polar. Aglikon berupa steroid yang bersifat non polar menyebabkan steroid lebih larut pada pelarut non polar.

\section{Hasil Ekstraksi}

Pembuatan maserat buah belimbing wuluh dilakukan dengan cara serbuk simplisia belimbing wuluh direndam dengan etanol $70 \%$. Pelarut ini dapat melarutkan senyawa fitokimia lebih maksimal karena etanol $70 \%$ masih mengandung air cukup banyak $(30 \%)$ yang membantu proses ekstraksi sehingga sebagian senyawa tersebut ada yang tertarik dalam etanol dan ada pula yang tertarik dalam air. Dari simplisia serbuk sebanyak 120 gram, diperoleh ekstrak pekat sebanyak 49,43 gram. Jadi, rendemen ekstrak diperoleh sebanyak 41,19\%.

\section{Hasil Uji Farmakologi pada Mencit}

Hewan coba yang digunakan pada penelitian ini adalah mencit (Mus musculus) jantan galur Swiss webster. Tidak digunakan yang betina karena pada mencit betina terjadi siklus estrus yang melibatkan hormon estrogen. Reseptor estrogen, ER $\alpha$, merupakan molekul yang berperan dalam metabolism glukosa, yang berperan dalam regulasi biosintesis insulin, sekresi insulin dan ketahanan sel $\beta$ pankreas.

Mencit (Mus musculus) dipilih sebagai model percobaan karena metabolism dalam tubuhnya serta rentang kadar glukosa darah normal yang dimiliki mirip dengan manusia. Kadar glukosa darah normal Mus musculus berada dalam rentang 85-132 mg/dL, sedangkan kadar glukosa darah puasa normal berada dalam rentang antara $50-109 \mathrm{mg} / \mathrm{dl}$.

Hewan coba yang digunakan adalah 30 mencit jantan yang dibagi dalam 6 kelompok, yaitu kelompok kontrol normal, kelompok kontrol negatif, kelompok kontrol positif, kelompok ekstrak dengan dosis bertingkat. Masing-masing kelompok terdiri dari 5 ekor mencit, berdasarkan perhitungan rumus Federer. Sebelumnya mencit ditimbang dengan berat rata-rata 27 gram dan dipuasakan selama 8 jam tapi tetap diberi minum ad libitum sebelum diberi perlakuan terapi.

Kemudian diukur glukosa darah puasa. Hal ini bertujuan untuk menghindari pengaruh makanan yang dapat mempengaruhi bahkan mempertinggi kadar glukosa darah jika mencit diinduksi aloksan. Pemeriksaaan kadar glukosa darah mencit pada penelitian ini menggunakan alat glukometer. Prinsip kerja penggunaan alat ini yaitu oksigen dengan bantuan enzim glukosa oksidase mengkatalis proses oksidasi glukosa menjadi asam glukonat dan hydrogen peroksida[18]. 
43 Eem Masaenah et al., (Aktivitas Ekstrak Etanol Buah Belimbing Wuluh...)

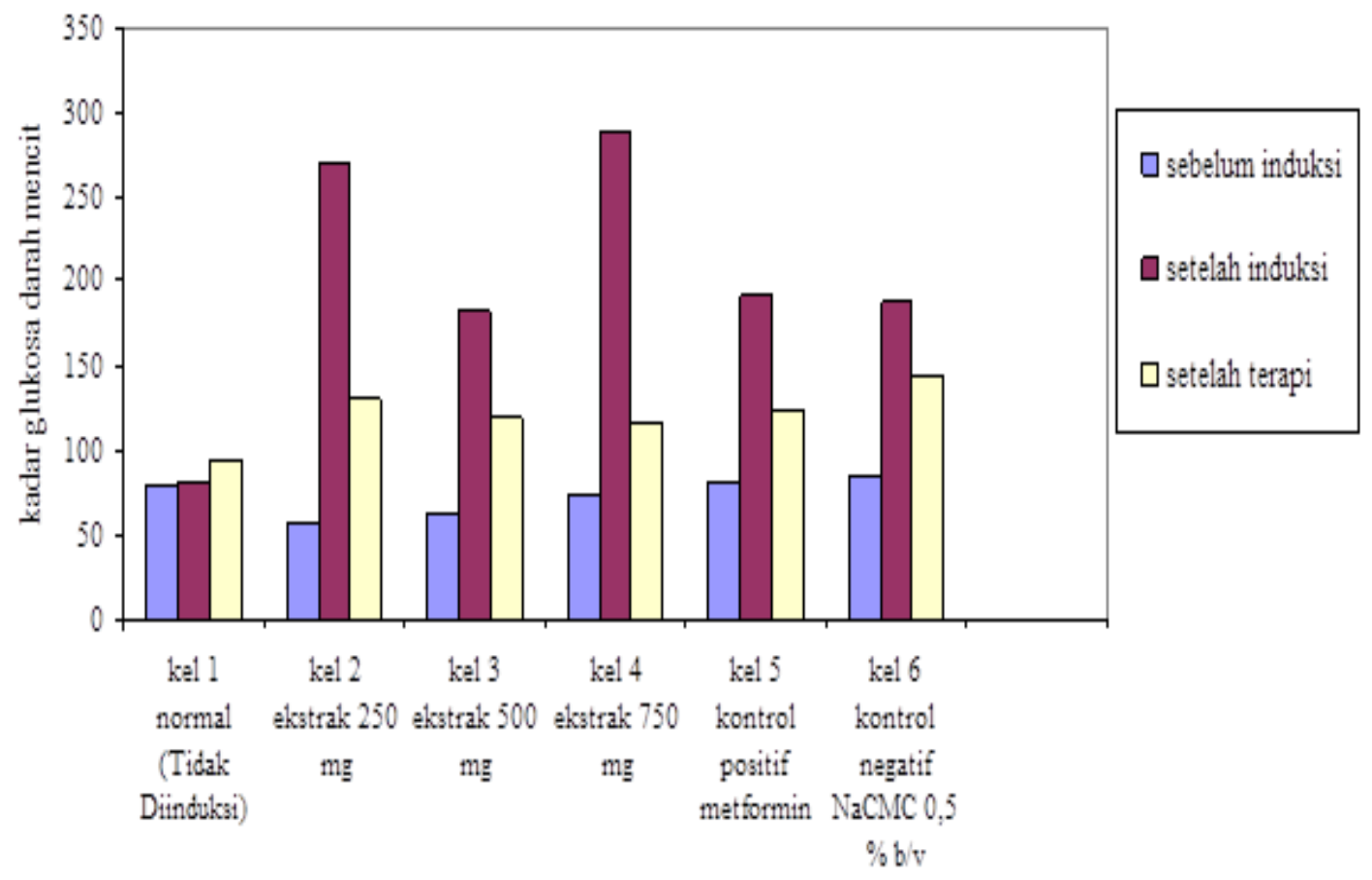

Kelompok Uji Antidiabetes

\section{Gambar 1. Rata-rata Kadar Glukosa Darah Mencit Sebelum dan Sesudah Diinduksi,} serta Setelah Terapi (Dosis/kgbb)

Gambar 1 menunjukkan rerata kadar glukosa darah puasa pada tiap kelompok mencit jantan sebelum diinduksi adalah $73,08 \mathrm{mg} / \mathrm{dl}$, masih dalam kisaran normal $(60-130 \mathrm{mg} / \mathrm{dl})$. Selanjutnya mencit diinduksi aloksan dengan dosis $120 \mathrm{mg} / \mathrm{kg}$ bb untuk membuat kondisi hiperglikemia [19].

Induksi aloksan dosis $120 \mathrm{mg} / \mathrm{kg} \mathrm{BB}$ dalam larutan $\mathrm{NaCl}$ terlihat secara bermakna meningkatkan kadar glukosa darah. Aloksan dipilih sebagai diabetogen karena di dalam tubuh, aloksan mengalami metabolism oksidasi reduksi yang menghasilkan radikal bebas dan radikal aloksan. Radikal ini mengakibatkan kerusakan sel beta pankreas, sehingga terjadi insulin dependent diabetes Melitus atau disebut alloxan diabetes pada hewan percobaan [14].

Meningkatnya kadar glukosa darah pada pemberian aloksan dapat disebabkan oleh dua proses yaitu terbentuknya radikal bebas dan kerusakan permeabilitas membran sel sehingga terjadi kerusakan sel beta pankreas yang berfungsi menghasilkan insulin. Senyawa flavonoid yang terdapat dalam belimbing wuluh (Averrhoa bilimbi L) diduga mempunyai kemampuan meregenerasi dan merangsang pelepasan insulin oleh sel beta pankreas[20].

Rata-rata kadar glukosa darah setelah diinduksi adalah 200,67 mg/dl, memenuhi kriteria DM tipe 2 dengan kisaran glukosa darah 200-349 mg/dl [15].Selanjutnya dilakukan perlakuan selama 7 hari, sekali dalam sehari pada pagi hari.

Tabel 2. Rerata Penurunan Glukosa Darah Mencit Setiap Kelompok Penelitian

\begin{tabular}{|l|c|c|c|}
\hline Kelompok & $\begin{array}{c}\text { Rerata Setelah } \\
\text { Induksi } \\
(\mathbf{m g} / \mathbf{d l}) \\
(\mathbf{G D P})\end{array}$ & $\begin{array}{c}\text { Rerata Setelah } \\
\text { Perlakuan }(\mathbf{m g} / \mathbf{d l}) \\
(\mathbf{G D P})\end{array}$ & $\begin{array}{c}\text { Persentase Penurunan } \\
\text { Kadar Glukosa Darah }\end{array}$ \\
\hline 1.Normal Tanpa Induksi & $81,75 \mathrm{mg} / \mathrm{dl}$ & $93,5 \mathrm{mg} / \mathrm{dl}$ & $-13 \%$ \\
\hline 2. Dosis $250 \mathrm{mg} / \mathrm{kg} \mathrm{BB}$ & $270,75 \mathrm{mg} / \mathrm{dl}$ & $131,25 \mathrm{mg} / \mathrm{dl}$ & $106 \%$ \\
\hline
\end{tabular}


44 Eem Masaenah et al., (Aktivitas Ekstrak Etanol Buah Belimbing Wuluh...)

\begin{tabular}{|c|c|c|c|}
\hline 3. Dosis $500 \mathrm{mg} / \mathrm{kg} \mathrm{BB}$ & $182,5 \mathrm{mg} / \mathrm{dl}$ & $119,75 \mathrm{mg} / \mathrm{dl}$ & $52 \%$ \\
\hline 4. Dosis $750 \mathrm{mg} / \mathrm{kg} \mathrm{BB}$ & $289,75 \mathrm{mg} / \mathrm{dl}$ & $115,5 \mathrm{mg} / \mathrm{dl}$ & $151 \%$ \\
\hline $\begin{array}{l}\text { 5. Kontrol Positif Induksi } \\
\text { suspensi Metformin }\end{array}$ & $191,25 \mathrm{mg} / \mathrm{dl}$ & $123,75 \mathrm{mg} / \mathrm{dl}$ & $55 \%$ \\
\hline $\begin{array}{l}\text { 6. Kontrol negatif } \\
\text { Induksi Suspensi } \\
\mathrm{Na} \text { CMC } 0,5 \% \text { b/v }\end{array}$ & $188 \mathrm{mg} / \mathrm{dl}$ & $143,25 \mathrm{mg} / \mathrm{dl}$ & $31 \%$ \\
\hline
\end{tabular}

Persentase penurunan kadar glukosa darah pada kelompok kontrol negatif yang diberi Na CMC sebesar $31 \%$, kemungkinan karena telah terjadi eliminasi kadar aloksan pada tubuh mencit. Sedangkan pada kelompok dosis $750 \mathrm{mg} / \mathrm{kg}$ bb mengalami penurunan yang signifikan sebesar $151 \%$ dibandingkan dengan kelompok dosis 250 $\mathrm{mg} / \mathrm{kg} \mathrm{bb}$, dengan penurunan $106 \%$. Pada kelompok dosis $500 \mathrm{mg} / \mathrm{kg}$ bb penurunan sebesar $52 \%$. Sedangkan pada kelompok normal tanpa diinduksi aloksan mengalami kenaikan kadar glukosa darah sebesar $13 \%$. Hal ini mungkin terjadi karena adanya pengaruh pemberian makanan pada mencit.

Penurunan kadar glukosa darah dengan ekstrak buah belimbing wuluh dosis 750 $\mathrm{mg} / \mathrm{kg}$ bb lebih baik dari kontrol positif yaitu metformin. Keadaan hiperglikemia yang terjadi pada mencit setelah diinduksi dengan aloksan adalah kerusakan sel beta pankreas, sehingga produksi dan sekresi insulin akan terhambat. Jadi,pemilihan tepat, karena mekanisme kerja metformin dalam tubuh yaitu dengan cara memperbaiki sensitivitas hepar dan jaringan perifer terhadap insulin tanpa mempengaruhi sekresi insulin [21].

Pada kelompok dosis $500 \mathrm{mg} / \mathrm{kg}$ bb memiliki persentase penurunan $52 \%$. Tidak jauh berbeda dengan kelompok kontrol positif (metformin) memiliki penurunan sebesar 55\%. Hal ini disebabkan pada saat penginduksian dengan aloksan, tidak terjadi peningkatan kadar glukosa darah >200 $\mathrm{mg} / \mathrm{dl}$.

Berdasarkan hasil uji homogenitas diperoleh nilai signifikansi $0,2>0,05$ dengan tingkat kepercayaan $95 \%$ sehingga Ho diterima artinya keenam kelompok perlakuan diambil dari populasi yang terdistribusi normal. Sampel yang terdistribusi normal dilanjutkan dengan uji One-way Anova untuk menguji perbedaan antar kelompok terhadap kadar glukosa darah.

Tabel 3. Ringkasan Anova Penurunan Kadar Glukosa Darah Setelah Terapi

\begin{tabular}{|l|l|l|l|l|l|}
\hline Sumber Variasi & Jumlah Kuadrat & Derajat Bebas & $\begin{array}{c}\text { Kuadrat } \\
\text { Rerata }\end{array}$ & F hitung & Probabilitas \\
\hline $\begin{array}{l}\text { Antar Kelompok } \\
\text { Dalam }\end{array}$ & 5582,333 & 5 & 1116,467 & 6,481 & 0,001 \\
$\begin{array}{l}\text { Kelompok } \\
\text { Total }\end{array}$ & 3101,000 & 18 & 172,278 & & \\
\hline
\end{tabular}

Berdasarkan uji Anova satu arah (tabel 3), menunjukkan penurunan kadar glukosa darah setelah terapi antar kelompok perlakuan berbeda nyata dengan nilai $\mathrm{p}<0,05$. Hal ini membuktikan bahwa pemberian ekstrak etanol $70 \%(\mathrm{P} 1, \mathrm{P} 2, \mathrm{P} 3)$ mampu menurunkan kadar glukosa darah mencit setelah dikondisikan DM yang menunjukkan bahwa metformin dan ekstrak etanol $70 \%$ buah belimbing wuluh mampu mengembalikan homeostasis glukosa yang terganggu akibat aloksan. Untuk mengetahui kelompok mana yang mempunyai perbedaan bermakna secara farmakologi, maka dilanjutkan dengan uji 
45 Eem Masaenah et al., (Aktivitas Ekstrak Etanol Buah Belimbing Wuluh...)

LSD. Ringkasan uji LSD dapat dilihat pada tabel 4.

Tabel 4. Perbedaan Rerata Penurunan Kadar Glukosa Darah Antar Kelompok dari Hasil Uji LSD

\begin{tabular}{|c|c|c|c|}
\hline \multirow[t]{16}{*}{ LSD } & \multirow{5}{*}{$\begin{array}{l}\text { Kelompok } \\
\text { Normal } \\
\text { Tanpa Induksi }\end{array}$} & Kelompok dosis $250 \mathrm{mg} / \mathrm{kgbb}$ & $-37,75000^{*}$ \\
\hline & & Kelompok dosis $500 \mathrm{mg} / \mathrm{kgbb}$ & $-26,25000^{*}$ \\
\hline & & Kelompok dosis obat $750 \mathrm{mg} / \mathrm{kg}$ bb & $-22,00000^{*}$ \\
\hline & & $\begin{array}{l}\text { Kelompok kontrol positif (Metformin } 65 \\
\mathrm{mg} / \mathrm{kg} \mathrm{bb} \text { ) }\end{array}$ & $-30,25000^{*}$ \\
\hline & & $\begin{array}{l}\text { Kelompok kontrol negatif (NaCMC } 0,5 \% \\
\text { b/v) }\end{array}$ & $-49,75000^{*}$ \\
\hline & $\begin{array}{l}\text { Kelompok dosis } \\
250 \mathrm{mg} / \mathrm{kgbb}\end{array}$ & Kelompok Normal (Tanpa Induksi) & $37,75000^{*}$ \\
\hline & \multirow{2}{*}{$\begin{array}{l}\text { Kelompok dosis } \\
500 \mathrm{mg} / \mathrm{kgbb}\end{array}$} & Kelompok Normal (Tanpa Induksi) & $26,25000^{*}$ \\
\hline & & $\begin{array}{l}\text { Kelompok Kontrol negatif ( NaCMC 0,5\% } \\
\text { b/v) }\end{array}$ & $-23,50000^{*}$ \\
\hline & \multirow{2}{*}{$\begin{array}{l}\text { Kelompok dosis } \\
750 \mathrm{mg} / \mathrm{kg} \mathrm{bb}\end{array}$} & Kelompok Normal (Tanpa Induksi) & $22,00000^{*}$ \\
\hline & & $\begin{array}{l}\text { Kelompok Kontrol negatif (NaCMC } 0,5 \% \\
\text { b/v) }\end{array}$ & $-27,75000^{*}$ \\
\hline & \multirow{2}{*}{$\begin{array}{l}\text { Kontrol } \\
\text { Positif(Metformi } \\
\text { n } 65 \mathrm{mg} / \mathrm{kg} \mathrm{bb} \text { ) }\end{array}$} & Kelompok Normal (Tanpa Induksi) & $30,25000^{*}$ \\
\hline & & $\begin{array}{l}\text { Kelompok Kontrol negatif (NaCMC } 0,5 \% \\
\text { b/v) }\end{array}$ & $-19,50000^{*}$ \\
\hline & \multirow{4}{*}{$\begin{array}{l}\text { Kontrol Negatif } \\
\text { (NaCMC } 0,5 \% \\
\text { b/v) }\end{array}$} & Kelompok Normal (Tanpa Induksi) & $49,75000^{*}$ \\
\hline & & Kelompok dosis $500 \mathrm{mg} / \mathrm{kgbb}$ & $23,50000^{*}$ \\
\hline & & Kelompok dosis $750 \mathrm{mg} / \mathrm{kg}$ bb & $27,75000^{*}$ \\
\hline & & $\begin{array}{l}\text { Kelompok Kontrol positif (Metformin } 65 \\
\mathrm{mg} / \mathrm{kg} \mathrm{bb} \text { ) }\end{array}$ & $19,50000^{*}$ \\
\hline
\end{tabular}

Hasil uji lanjutan LSD menunjukkan kelompok kontrol negatif (NaCMC $0,5 \%$ b/v) memiliki perbedaan yang bermakna pada tingkat kepercayaan $95 \%$ terhadap kontrol positif dan kelompok ekstrak dengan dosis $500 \mathrm{mg} / \mathrm{kg} \mathrm{bb}, 750 \mathrm{mg} / \mathrm{kg}$ bb. Hal ini menunjukkan bahwa pemberian ekstrak etanol $70 \%$ dengan dosis 750 $\mathrm{mg} / \mathrm{kg}$ bb berpengaruh terhadap penurunan kadar glukosa darah. Dosis $750 \mathrm{mg} / \mathrm{kg}$ bb mencit memiliki aktivitas yang lebih baik dari kontrol positif bila dibandingkan dengan kontrol negatif. Sedangkan dosis $250 \mathrm{mg} / \mathrm{kg}$ bb memiliki aktivitas yang hampir sama dengan kontrol negatif.

Kelompok ekstrak sama dengan kelompok kontrol positif. Ini menunjukkan bahwa pemberian ekstrak memiliki efek menurunkan kadar glukosa darah.
Kelompok kontrol positif metformin 65 $\mathrm{mg} / \mathrm{kg}$ bb memiliki perbedaan yang bermakna terhadap kelompok kontrol negatif dan kontrol normal. Hal ini menunjukkan kelompok dosis $250 \mathrm{mg} / \mathrm{kg}$ $\mathrm{bb}, 500 \mathrm{mg} / \mathrm{kg} \mathrm{bb}$, dan $750 \mathrm{mg} / \mathrm{kg} \mathrm{bb}$ memiliki aktivitas yang hampir sama dengan kontrol positif.

Flavonoid memiliki efek hipoglikemik dengan beberapa mekanisme yaitu dengan menghambat absorpsi glukosa, meningkatkan toleransi glukosa, merangsang pelepasan insulin atau bertindak seperti insulin, meningkatkan pengambilan glukosa oleh jaringan perifer serta mengatur enzim-enzim yang berperan dalam metabolisme karbohidrat. Penelitian ini menunjukkan bahwa ekstrak etanol 70 $\%$ buah belimbing wuluh memiliki potensi 
46 Eem Masaenah et al., (Aktivitas Ekstrak Etanol Buah Belimbing Wuluh...)

sebagai alternatif terapi diabetes pelengkap dalam upaya pemeliharaan kesehatan pasien diabetes melitus.

\section{SIMPULAN}

Pemberian ekstrak etanol $70 \%$ buah belimbing wuluh selama 7 hari dengan dosis $250 \mathrm{mg} / \mathrm{kg} \mathrm{bb}, 500 \mathrm{mg} / \mathrm{kg}$ bb, dan $750 \mathrm{mg} / \mathrm{kg}$ bb memberikan efek terhadap penurunan kadar glukosa darah mencit yang diinduksi dengan aloksan.

Pemberian ekstrak etanol $70 \%$ buah belimbing wuluh dosis $750 \mathrm{mg} / \mathrm{kg} \mathrm{bb}$ mampu menurunkan kadar glukosa darah secara signifikan dengan persentase penurunan antara kadar glukosa darah sesudah induksi dan sesudah terapi sebesar $151 \%$. Hal ini lebih baik dibandingkan dengan kontrol positif yakni metformin 65 $\mathrm{mg} / \mathrm{kg}$ bb dengan penurunan sebesar $55 \%$.

\section{DAFTAR PUSTAKA}

[1] Setiawan dan Felix A. 2012. Makanan dan Herbal untuk Penderita Diabetes Melitus. B. Prasetya W., Editor. Jakarta: Penebar Swadaya.

[2] Septhi. 2012. Ekstrak Akar, Batang dan Daun Herba Meniran dalam Menurunkan Kadar GlukosaDarah. Jurnal Kesehatan : 51-59.

[3] Rezchy, D. A. et al. 2014. Uji Efektivitas Penurunan Kadar Gula Darah Ekstrak Etanol, Daun Sendok (Plantago major L.) pada Tikus Putih Jantan Galur Wistar (Ratus novergicus) yang Diinduksi Sukrosa. Pharmacon. Vol 3: 135.

[4] Puspharaj, P., Tan C.H., and Tan BK. 2000. Effects of Avverhoa bilimbi leaf extract on blood glucose and lipids in streptozotocin-diabetics rats, Journal Ethnopharmacol. 72 (1-2):6976.

[5] Cahyaning, G,A.2012. Efek Ekstrak Batang Belimbing Wuluh (Averrhoa bilimbi L) terhadap Kadar Gula Darah Tikus Putih (Rattus novergicus) yang
Diinduksi Aloksan. [Skripsi]. Surakarta. Universitas Sebela sMaret.

[6] Sutrisna, et al., 2012. Uji Praklinis Efek Hipoglikemi Belimbing Wuluh (Averrhoa bilimbi L.) dan DaunTapak Dara (Catharanthus roseus G). Pharmacon. Vol 13: 37-40.

[7] Elsa, et al. 2014. Efek Infusa Belimbing Wuluh (Averrhoa bilimbi L) dalam Menurunkan Kadar Glukosa Darah Puasa dan 2 Jam Post Prandial Mencit Model Diabet. [Prosiding Pendidikan Dokter]. Universitas Islam Bandung.

[8] Stefani Candra. 2012. Pengaruh Pemberian Ekstrak Buah Belimbing Wuluh (Averrhoa bilimbi L) terhadap Penurunan Kadar Glukosa Darah Tikus Wistar yang Diinduksi Aloksan [Karya Tulis Ilmiah]. Semarang: Universitas Diponegoro.

[9] Ditjen POM, 2000. Parameter Standar Umum Ekstrak Tumbuhan Obat. Cetakan Pertama. Jakarta :Departemen Kesehatan RI.

[10] Ditjen POM, 1995. Materia Medika Indonesia, Jilid VI. Jakarta: Departemen Kesehatan RI Hal. 103113.

[11] Harborne, J.B. 1987. Metode Fitokimia: Penuntun Cara Modern Menganalisis Tumbuhan. Bandung: Institut Teknologi Bandung.

[12] Chaiyatullah et al. 2013. Efek Infusa Daun Sirsak (Annona muricata L) terhadap Kadar Glukosa Darah Tikus Putih (Rattus novergicus)Jantan Galur Wistar yang Dibebani Glukosa. [Naskah Publikasi] Fakultas Kedokteran Universitas Tanjungpura Pontianak.

[13] ReesD, A and Alcolado, J. C. 2005. Animal models of diabetes Melitus, Diabetic Medicine. 22 : 359-370.

[14] Szkudelski, T. 2001. The Mechanism Of Alloxan And Streptozotocin Action In $\beta$ Cells Of The Rat 
47 | Eem Masaenah et al., (Aktivitas Ekstrak Etanol Buah Belimbing Wuluh...)

Pancreas, Physiology Research, 50: 536-54.

[15] Masagus, M.T. 2009. Kadar Insulin Plasma Mencit yang Dikondisikan Diabetes Melitus setelah Pemberian Ekstrak Air Daun Nimba. Di dalam: Prosiding Seminar Nasional Penelitian Universitas Negeri Yogyakarta, 16 Mei 2009.

[16] Purwatresna, E. 2012. Aktivitas Antidiabetes Ekstrak Air dan Etanol Daun Sirsak Secara In Vitro melalui Inhibisi Enzim A-Glukosidase. Institut Pertanian Bogor. Bogor. 2012.

[17] Robinson T. 1995. Kandungan Organik Tumbuhan Tinggi. ITB Bandung.Hal. 71 153-156, 191dan 281.
[18] Manurung, D.T. 2012. Pengaruh Pemberian Ekstrak Kulit Batang Kayu Raru (Vatica pauciflora Blume) sebagai Antidiabetes terhadap Tikus Wistar yang Diinduksi Aloksan. Universitas Negeri Medan. Medan.

[19] Agung E.N.2006. Hewan Percobaan Diabetes Melitus: Patologi dan Mekanisme Aksi Diabetogenik. Biodiversitas: 378-379.

[20] Dheer R. dan Bhatnagar P. 2010. A study of the Antidiabetic Activity of Barleriaprionitis Linn. Indian Journal of Pharmacology. 42 (2): 70-73.

[21] Suharti dan Suherman. 2007. Insulin dan Antidiabetik Oraldalam Farmakologi dan Terapi edisi ke-5. Jakarta: Bagian Farmakologi Fakultas Kedokteran Universitas Indonesia, pp:490-495. 